\title{
Changes in treatment patterns and survival in elderly patients with stage I non-small-cell lung cancer with the introduction of stereotactic body radiotherapy and video-assisted thoracic surgery
}

Citation for published version (APA):

Detillon, D. D. E. M. A., Driessen, E. J. M., Aarts, M. J., Janssen-Heijnen, M. L. G., van Eijck, C. H. J., \& Veen, E. J. (2018). Changes in treatment patterns and survival in elderly patients with stage I non-smallcell lung cancer with the introduction of stereotactic body radiotherapy and video-assisted thoracic surgery. European Journal of Cancer, 101, 30-37. https://doi.org/10.1016/j.ejca.2018.06.016

Document status and date:

Published: 01/09/2018

DOI:

10.1016/j.ejca.2018.06.016

Document Version:

Publisher's PDF, also known as Version of record

Document license:

Taverne

Please check the document version of this publication:

- A submitted manuscript is the version of the article upon submission and before peer-review. There can be important differences between the submitted version and the official published version of record. People interested in the research are advised to contact the author for the final version of the publication, or visit the DOI to the publisher's website.

- The final author version and the galley proof are versions of the publication after peer review.

- The final published version features the final layout of the paper including the volume, issue and page numbers.

Link to publication

\footnotetext{
General rights rights.

- You may freely distribute the URL identifying the publication in the public portal. please follow below link for the End User Agreement:

www.umlib.nl/taverne-license

Take down policy

If you believe that this document breaches copyright please contact us at:

repository@maastrichtuniversity.nl

providing details and we will investigate your claim.
}

Copyright and moral rights for the publications made accessible in the public portal are retained by the authors and/or other copyright owners and it is a condition of accessing publications that users recognise and abide by the legal requirements associated with these

- Users may download and print one copy of any publication from the public portal for the purpose of private study or research.

- You may not further distribute the material or use it for any profit-making activity or commercial gain

If the publication is distributed under the terms of Article 25fa of the Dutch Copyright Act, indicated by the "Taverne" license above,

Download date: 26 Apr. 2023 


\title{
Changes in treatment patterns and survival in elderly patients with stage I non-small-cell lung cancer with the introduction of stereotactic body radiotherapy and video-assisted thoracic surgery
}

\author{
Deniece D.E.M.A. Detillon ${ }^{a, *}$, Elisabeth J.M. Driessen ${ }^{\text {b,c }}$, \\ Mieke J. Aarts ${ }^{d}$, Maryska L.G. Janssen-Heijnen ${ }^{\text {b,c }}$, \\ Casper H.J. van Eijck ${ }^{\mathrm{e}}$, Eelco J. Veen ${ }^{\mathrm{a}}$ \\ a Department of Surgery, Amphia Hospital, Breda, The Netherlands \\ ${ }^{\mathrm{b}}$ Department of Clinical Epidemiology, VieCuri Medical Centre, Venlo, The Netherlands \\ ${ }^{\mathrm{c}}$ Department of Epidemiology, GROW - School for Oncology and Developmental Biology, Maastricht University Medical \\ Centre, Maastricht, The Netherlands \\ ${ }^{\mathrm{d}}$ Netherlands Cancer Registry, Netherlands Comprehensive Cancer Organization, Utrecht, The Netherlands \\ e Department of Surgery, Erasmus Medical Center, Rotterdam, The Netherlands
}

Received 5 December 2017; received in revised form 8 June 2018; accepted 14 June 2018

Available online 14 July 2018

\author{
KEYWORDS \\ Early-stage lung \\ cancer; \\ Elderly; \\ Surgery; \\ Video-assisted thoracic \\ surgery; \\ Radiotherapy; \\ Stereotactic body \\ radiotherapy; \\ Treatment patterns; \\ Overall survival; \\ Epidemiology
}

\begin{abstract}
Background: The optimal treatment of elderly patients with early-stage non-smallcell lung cancer (NSCLC) remains elusive. Still, the introduction of video-assisted thoracic surgery (VATS) and stereotactic body radiotherapy (SBRT) may have led to more elderly receiving treatment and improved median overall survival (OS).

Materials and methods: We analysed data from the Netherlands Cancer Registry of 2168 patients $\geq 65$ years with clinical stage I NSCLC and distinguished two periods: 2004-2008 (A) and 2009-2013 (B). The analyses focussed on treatment patterns and median OS for patients receiving surgery, radiotherapy or neither surgery nor radiotherapy. Furthermore, we explored the influence of the application of VATS and SBRT.

Results: The resection rate did not differ between the periods A and B (51\% versus 53\%; $\mathrm{p}=0.37)$, despite significantly more VATS procedures in the latter period $(0 \%$ versus $32 \%$; $\mathrm{p}<0.001)$. Application of radiotherapy increased ( $26 \%$ versus $33 \% ; \mathrm{p}=0.001)$, especially SBRT $(3 \%$ versus $63 \%$; $<0.001)$. The proportion of patients receiving neither therapy decreased $(23 \%$ versus $14 \% ; \mathrm{p}<0.001)$. Median OS for all patients significantly improved
\end{abstract}

\footnotetext{
* Corresponding author.

E-mail addresses: DDetillon@amphia.nl (D.D.E.M.A. Detillon), ldriessen@viecuri.nl (E.J.M. Driessen), M.Aarts@iknl.nl (M.J. Aarts), mjanssenheijnen@viecuri.nl (M.L.G. Janssen-Heijnen), c.vaneijck@erasmusmc.nl (C.H.J. van Eijck), EVeen@amphia.nl (E.J. Veen).
} 
(31 versus 42 months; $\mathrm{p}=0.001)$, and also for those receiving radiotherapy (23 versus 33 months; $p=0.02$ ), but not significantly for surgical patients (65 versus 74 months; $\mathrm{p}=0.16)$. Still, in multivariable analysis, surgical patients had an increased risk of death in period A compared with period B (hazard ratio [HR] 1.20; 95\% confidence interval [CI], 1.01-1.43); this was not the case for patients receiving radiotherapy (HR 1.19; $95 \% \mathrm{CI}$, $0.99-1.43$ ). Five-year OS was $57 \%$ for surgical patients and $23 \%$ for those receiving radiotherapy.

Conclusion: In elderly patients with stage I NSCLC, the use of surgery remained constant, that of radiotherapy increased and fewer patients received neither treatment over the years. Median OS improved for all patients; surgery was associated with the highest long-term OS.

(C) 2018 Elsevier Ltd. All rights reserved.

\section{Introduction}

Lung cancer is the leading cause of cancer death worldwide [1] and in the Netherlands [2]. The highest incidence rates are found among women aged 65-69 years and among men aged $70-74$ years [3]. On the basis of demographic developments, the absolute number of new cases of lung cancer in the Netherlands is expected to increase by $46 \%$ for men and $24 \%$ for women between 2015 and 2040 [4]. Only small improvements in overall survival (OS) have been reported so far. Driessen et al. found that 5 -year relative survival for patients $\geq 70$ years in the Netherlands had increased from $12 \%$ in 1990-1994 to $16 \%$ in 2010-2014 [5].

Surgery offers the best potential cure for early-stage non-small-cell lung cancer (NSCLC). It is not always offered, however, to elderly patients in view of their advanced age and comorbidities [6]. In a study by Palma et al., $38 \%$ of 875 patients $\geq 75$ years with stage I NSCLC did not receive any form of treatment [7]. The outcome of surgery can potentially be improved by video-assisted thoracic surgery (VATS) [8]. In previous studies, VATS was superior to thoracotomy in terms of postoperative morbidity, even in octogenarians [9-11]. For patients who are inoperable because of comorbidities, radiotherapy is an alternative treatment with curative intent [8]. Shirvani et al. reported that stereotactic body radiotherapy (SBRT) offers better long-term OS than external beam radiotherapy [12]. SBRT makes use of high doses of radiation in a limited number of fractions, thereby avoiding damage to organs close to the tumour [13]. In a study by Haasbeek et al., the application of SBRT in Dutch patients $\geq 75$ years with stage I NSCLC was associated with a 9-month improvement in OS over the period 2001-2009 [8].

New technologies, such as VATS and SBRT, have gained acceptance by now. The question is, however, whether treatment is offered to more elderly patients now and whether the OS has improved. To answer this question, we performed a study evaluating changes in treatment patterns and OS for patients $\geq 65$ years with clinical stage I NSCLC.

\section{Materials and methods}

Population-based data from the southern region of the Netherlands Cancer Registry (NCR) were used. This region covers 2.4 million inhabitants $(15 \%$ of the Dutch population). The NCR records data of all patients newly diagnosed with cancer. The NCR automatically receives notifications of all newly diagnosed malignancies from the nationwide network and registry of histopathology and cytopathology in the Netherlands. Additional sources are radiotherapy institutes and the Dutch national registry of hospital discharge. These data are supplemented with data from medical records, including patient characteristics (such as age, sex and comorbidities) and tumour characteristics (such as the date of diagnosis, tumour type, histology, stage and treatment). The type of surgery is recorded in the database, whereas details of radiotherapy such as dose or fraction are missing. We selected data from the southern region because information on comorbidities is routinely collected in this region only. Information on vital status was obtained from the population registries network. Cause of death was not available. Follow-up data were complete until February 2017.

We retrieved data of all patients $\geq 65$ years diagnosed between 2004 and 2013 with clinical stage I NSCLC, according to the International Union Against Cancer tumour-node-metastasis (TNM) edition 6 and 7 (from 2010 onwards). Treatment patterns and median OS were assessed for two periods: 2004-2008 (period A) and 2009-2013 (period B). In 2004, fluorodeoxyglucose positron emission tomography (FDG-PET) scanning has been incorporated in the national guideline for NSCLC in the Netherlands. PET scans were introduced gradually in the Netherlands and became a more common practice between 2005 and 2008. Endoscopic ultrasound/endobronchial ultrasound has become more common in daily clinical practice since 2010 and was incorporated in the national guideline in 2011. In the Netherlands, SBRT became available in 2003 and became widespread after 2007 [8]. In 2006, the first VATS lobectomy was performed in the Netherlands 
[14]. Treatment was classified as surgery, including thoracotomy and VATS; radiotherapy, including conventional radiotherapy and SBRT or neither of these. Patients in the latter category were offered chemotherapy, targeted therapy or best supportive care. Demographic variables retrieved were age and sex. Age was dichotomised as $65-74$ years and $\geq 75$ years. Comorbidities were grouped as cardiac, vascular, pulmonary, diabetes or previous malignancy. Tumour characteristics included clinical tumour stage, histology (adenocarcinoma, squamous cell carcinoma and other) and the presence or absence of histopathologic confirmation. Dutch national radiotherapy guidelines indicate that patients without pathologic confirmation receive radiotherapy in case of (a) a new or growing lesion on computed tomography scans with characteristics of malignancy; (b) a high risk for developing lung cancer based on age and smoking history and (c) an FDGPET-positive lesion [15]. The probability of benign disease in these patients is only $4.3 \%$ [16]. Criteria to perform lung surgery were in accordance with the Dutch practice guidelines for the treatment of NSCLC [17].

\subsection{Statistical analysis}

Baseline differences between the two treatment periods on one hand and the three treatment groups on the other hand were compared using the $\chi^{2}$ test. Kaplan-Meier estimates of median OS were calculated, and the logrank test was used to detect significant differences. Specific factors associated with an increased hazard ratio (HR) of death were determined with Cox regression analysis. A number of candidate factors were selected on the basis of a statistically significant association with an increased HR of death in previous studies. These were age [12], sex [12], clinical tumour stage [7], histopathologic confirmation [7] and a more recent period in time $[7,8]$. In addition, the following factors expected to be associated were included: cardiac, vascular and pulmonary comorbidities; a history of diabetes and a previous malignancy. An HR $>1.0$ with a $95 \%$ confidence interval (CI) completely $>1.0$ indicates a significant worse outcome. All statistical tests were two sided, and $\mathrm{p} \leq 0.05$ was considered to indicate statistical significance. Statistical analyses were performed using SPSS statistical software (SPSS, version 22; Chicago, IL).

\section{Results}

Between 2004 and 2013, a total of 2168 patients $\geq 65$ years (1068 in period A and 1100 in period B) with clinical stage I NSCLC were diagnosed in the southern region of the Netherlands (Fig. 1). In period A, no VATS resections were performed and SBRT was offered to nine patients. The mean age was 73.8 (standard deviation 5.7) years, and $30 \%$ were female. Median followup was 37 months for the entire group and 52 months, 29 months and 12 months for patients receiving surgery, radiotherapy and neither treatment, respectively.

Surgical patients were younger and had statistically significant less often cardiac, vascular and pulmonary comorbidities than patients in the other groups. Pathological upstaging was documented for 206 patients (18\%) after surgery; cT1-2 became pT3-4 in 52 patients, and cN0 became pN1-2 in 171 patients. Seventeen patients were upstaged to pT3-4 and pN1-2. Adjuvant treatment was administered to 92 upstaged patients $(45 \%) ; 61$ patients received chemotherapy, 26 received radiotherapy, four underwent chemoradiation and one patient was treated with targeted therapy. No histopathologic proof of malignancy was obtained in $72 \%$ of patients receiving radiotherapy and $68 \%$ of patients receiving neither treatment.

The analysis results are consistent generally with a trend towards greater proportions of patients with comorbidities in period B (Table 1). The proportion of surgical patients with cardiac and pulmonary

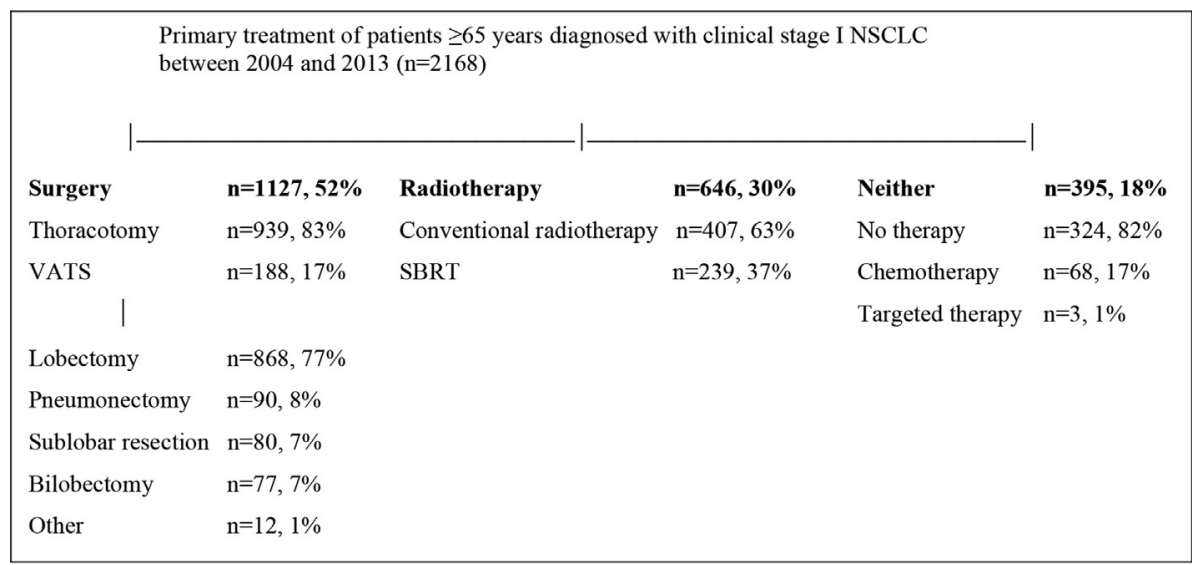

Fig. 1. CONSORT diagram of patients and primary treatment. NSCLC, non-small-cell lung cancer; VATS, video-assisted thoracic surgery; SBRT, stereotactic body radiotherapy. 
Table 1

Baseline characteristics of patients $\geq 65$ years with clinical stage I NSCLC treated with surgery, radiotherapy or neither.

\begin{tabular}{|c|c|c|c|c|c|c|}
\hline \multirow[t]{2}{*}{ Characteristics } & \multicolumn{2}{|l|}{ Surgery } & \multicolumn{2}{|c|}{ Radiotherapy } & \multicolumn{2}{|l|}{ Neither } \\
\hline & $\begin{array}{l}\text { Period A } \\
(\mathrm{n}=543)\end{array}$ & $\begin{array}{l}\text { Period B } \\
(\mathrm{n}=584)\end{array}$ & $\begin{array}{l}\text { Period A } \\
(\mathrm{n}=281)\end{array}$ & $\begin{array}{l}\text { Period B } \\
(\mathrm{n}=365)\end{array}$ & $\begin{array}{l}\text { Period A } \\
(\mathrm{n}=244)\end{array}$ & $\begin{array}{l}\text { Period B } \\
(\mathrm{n}=151)\end{array}$ \\
\hline \multicolumn{7}{|l|}{ Age, n (\%) } \\
\hline $65-74$ years & 418 (77) & $412(71)$ & $105(37)$ & $166(46)$ & $94(39)$ & $45(30)$ \\
\hline$\geq 75$ years & $125(23)$ & $172(29)$ & $176(63)$ & $199(54)$ & $150(62)$ & $106(70)$ \\
\hline Male sex, n (\%) & $391(72)$ & $395(68)$ & 209 (74) & $234(64)$ & $173(71)$ & $108(72)$ \\
\hline \multicolumn{7}{|l|}{ Comorbidities, n (\%) } \\
\hline Cardiac & $171(32)$ & 206 (35) & $108(38)$ & $151(41)$ & $88(36)$ & $76(50)$ \\
\hline Vascular & $128(24)$ & $144(25)$ & $86(31)$ & $122(33)$ & $68(28)$ & $44(29)$ \\
\hline Pulmonary & $176(33)$ & $210(36)$ & $165(59)$ & $212(58)$ & $115(47)$ & $73(48)$ \\
\hline Diabetes & $78(14)$ & $90(15)$ & $51(18)$ & $69(19)$ & $40(16)$ & $27(18)$ \\
\hline Previous malignancy & 93 (17) & $150(26)$ & $58(21)$ & $106(29)$ & $56(23)$ & $37(25)$ \\
\hline Unknown & $13(2)$ & $45(8)$ & $7(3)$ & $19(5)$ & $6(3)$ & $8(3)$ \\
\hline \multicolumn{7}{|l|}{ cT stage, n (\%) } \\
\hline 1 & $234(43)$ & 298 (51) & $53(19)$ & $172(47)$ & $23(9)$ & $28(19)$ \\
\hline 2 & $245(45)$ & $235(40)$ & 103 (37) & $98(27)$ & $109(45)$ & $56(37)$ \\
\hline Unknown & $64(12)$ & $51(9)$ & $125(44)$ & $95(26)$ & $112(46)$ & $67(44)$ \\
\hline \multicolumn{7}{|l|}{ Histology pretreatment } \\
\hline Adenocarcinoma & $251(46)$ & 228 (39) & $68(24)$ & $70(19)$ & $64(26)$ & $30(20)$ \\
\hline Squamous cell carcinoma & $192(35)$ & $261(45)$ & $29(10)$ & $62(17)$ & $15(6)$ & $18(12)$ \\
\hline Other & $100(18)$ & $95(16)$ & $184(66)$ & $233(64)$ & $165(68)$ & $103(68)$ \\
\hline Histopathologic confirmation, n (\%) & $543(100)$ & $584(100)$ & $90(32)$ & $92(25)$ & $83(34)$ & $45(30)$ \\
\hline
\end{tabular}

NSCLC, non-small-cell lung cancer.

Statistics in bold indicate a statistical significant difference between period A and B ( $\mathrm{p} \leq 0.05)$

comorbidities, as well as a previous malignancy, had even significantly increased. An ageing phenomenon was seen: $23 \%$ of surgical patients in period A were aged $\geq 75$ years versus $29 \%$ in period $\mathrm{B}(\mathrm{p}=0.01)$. The opposite held for patients receiving radiotherapy: $63 \%$ of patients in period A were aged $\geq 75$ years versus $54 \%$ in period $B$ $(\mathrm{p}=0.04)$.

The resection rate did not differ between the periods A and B ( $p=0.37$, Fig. 2), although in period B, almost one-third of surgical patients had been treated with VATS, versus nil in period A $(\mathrm{p}<0.001)$. The application of radiotherapy had increased $(\mathrm{p}=0.001)$, especially SBRT (3\% versus63\%; $p<0.001)$. In period $\mathrm{B}$, fewer patients than in period $\mathrm{A}$ had received neither treatment modality $(\mathrm{p}<0.001)$.

The estimated median OS time for surgery, radiotherapy and neither therapy, respectively, was 69 months, 29 months and 12 months $(\mathrm{p}<0.001)$. Long-

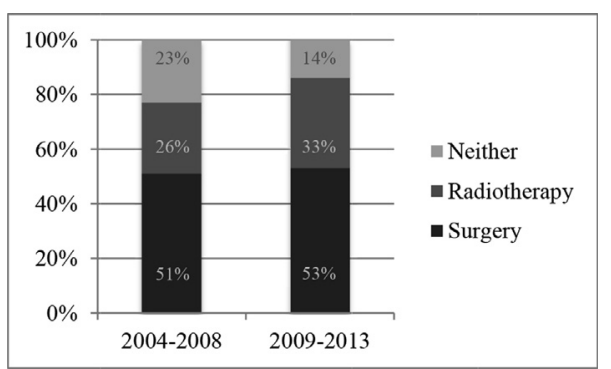

Fig. 2. Treatment patterns among patients $\geq 65$ years with clinical stage I NSCLC diagnosed between 2004 and 2013. NSCLC, non-small-cell lung cancer. term OS was better for patients who underwent surgery (p $<0.001$; Fig. 3).

Fig. 4 shows Kaplan-Meier estimates of the OS in either time period. The median OS for all patients had increased from 31 months to 42 months $(p=0.001)$ and that for surgical patients, from 65 months to 74 months $(\mathrm{p}=0.16)$. The 2-year and 5-year OS for surgical patients was $75 \%$ and $52 \%$, respectively, in period $\mathrm{A}$, and had improved to $78 \%$ and $57 \%$, respectively, in period B, albeit not statistically significantly. For patients receiving radiotherapy, the median OS was 23 months in period $\mathrm{A}$ and 33 months in period $\mathrm{B}(\mathrm{p}=0.02)$. Their 2-year and 5 -year OS had improved statistically significantly from $48 \%$ and $21 \%$, respectively, in period A, to $66 \%$ and $23 \%$, respectively, in period $\mathrm{B}$. The median OS for patients receiving neither treatment had declined from 12 months in period A to 11 months in period $\mathrm{B}(\mathrm{p}=0.98)$.

The adjusted hazard of death had increased over time among all patients $\geq 75$ years (HR 1.49; 95\% CI, 1.34-1.66), as well as among all individual subgroups of patients $\geq 75$ years (Table 2 ). Hazards of death had also increased in all patients with cardiac and pulmonary comorbidities, diabetes and a previous malignancy, as well as in the subgroup of surgical patients. Among all patients, no histopathologic proof of malignancy was associated with an increased risk of death (HR 1.64; 95\% CI, 1.43-1.87). The opposite was true for patients receiving radiotherapy (HR $0.76 ; 95 \% \mathrm{CI}, 0.61-0.94$ ). For all patients, treatment in period $\mathrm{A}$ was associated with a higher hazard of death in comparison with period B. This held for the subgroup of surgical patients as 


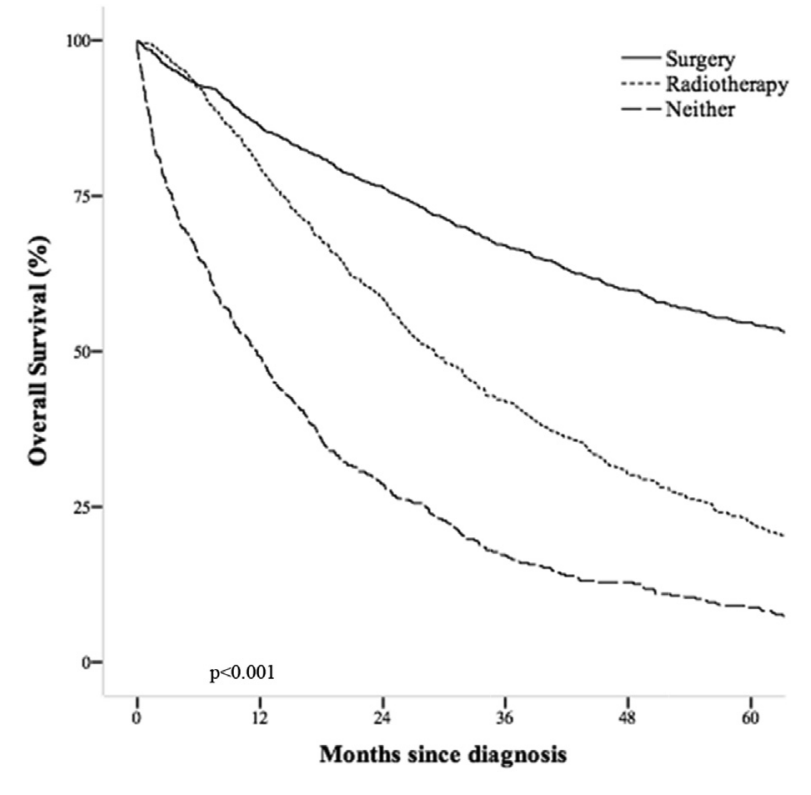

No. at risk

$\begin{array}{lrrrrrr}\text { Surgery } & 1127 & 974 & 863 & 756 & 676 & 616 \\ \text { Radiotherapy } & 646 & 516 & 377 & 271 & 195 & 145 \\ \text { Neither } & 395 & 194 & 113 & 68 & 51 & 35\end{array}$

Fig. 3. Overall survival for patients $\geq 65$ years with clinical stage I NSCLC by primary treatment (2004-2013). NSCLC, non-smallcell lung cancer.

well but not for patients receiving radiotherapy. Univariable analysis of clinical $\mathrm{T}$ stage demonstrated that T2 disease was associated with an increased risk of death in all patients, as well as the subgroups of patients receiving surgery and radiotherapy.

\section{Discussion}

This study demonstrates a shift in treatment pattern and median OS between 2004 and 2013 in patients $\geq 65$ years with clinical stage I NSCLC. The resection rate remained constant over time, although the latter period was characterised by a fair number of VATS procedures, versus nil in the former period. The proportion of patients receiving radiotherapy, especially the application of SBRT, had increased significantly in the latter period, and therefore, the proportion of patients receiving neither therapy decreased. The median OS in the total patient population had significantly increased. In surgical patients, the median OS and the 2-year and 5-year OS were higher compared with those receiving radiotherapy.

Although not statistically significant, the median OS of patients who underwent surgery had improved with 9 months in the latter 4-year period. Use of surgery remained constant between the time periods, while surgical patients were treated at a higher age, and the comorbidity burden had increased in the latter period. Pulmonary and cardiac comorbidities, as well as higher age, are associated with higher mortality rates and lower OS rates in NSCLC patients $[9,18]$. The risk of death had increased in surgical patients with pulmonary and cardiac comorbidities, which might explain why the OS had not statistically significantly improved. Still, after adjustment for the factors in the multivariable model, statistical significance of OS improvement was shown as surgical treatment in period A was associated with an increased risk of death. The increased adjusted risk of death in period A is likely due to the fact that no VATS procedures were performed during this period. Indeed, Zhang et al. showed significant better long-term OS rates after VATS in a meta-analysis on studies comparing open lobectomy with VATS lobectomy for early-stage NSCLC [19].

Median OS improved with 10 months for patients receiving radiotherapy, which is in accordance with an almost 10-month improvement reported in a previous study among elderly patients [8]. This cannot be solely ascribed to the introduction of SBRT as the risk of death for these patients was not higher in the earlier period in which SBRT was virtually unavailable. Significant improvements in OS disappear over time after adjustment for the factors in the multivariable model. In addition, patients receiving radiotherapy in period A were significantly older than those in period B. As expected, older age was associated with an increased risk of death in all treatment groups. Because SBRT was associated with a better OS than conventional radiotherapy in multiple studies [7,12], the improved OS might in part be explained by the combination of SBRT and lower age of patients in period B. It would be interesting to examine which subgroup of patients benefits the most from SBRT in a future trial. The finding that in period $\mathrm{B}$ fewer patients received neither therapy can perhaps be ascribed to the increase in the proportion of patients receiving radiotherapy. In a study by Palma et al., the introduction of SBRT had enhanced the accessibility of curative treatment for patients with stage I NSCLC $\geq 75$ years and reduced the number of untreated patients by $12 \%$ [7].

A significantly higher median OS was found for surgical patients compared with those receiving radiotherapy (69 versus 29 months). Puri et al. compared surgery with SBRT in 117,618 patients with clinical stage I NSCLC. The long-term OS was significantly better in surgical patients (68 months versus 33 months, $\mathrm{p}<0.001$ ), even in a propensity-matched comparison (62 months versus 33 months, $\mathrm{p}<0.001$ ) [20]. The results from randomised control trials are inconclusive, however, and additional randomised studies should answer the question whether SBRT is a valid alternative for elderly patients with operable stage I NSCLC [21].

The results of this study must be seen in the context of its strengths and limitations. The main strength is the large sample size and the availability of information on comorbidities, which is often lacking in other studies comparing treatment modalities $[7,8]$. Furthermore, the patient population truly reflected clinical practice; it did 

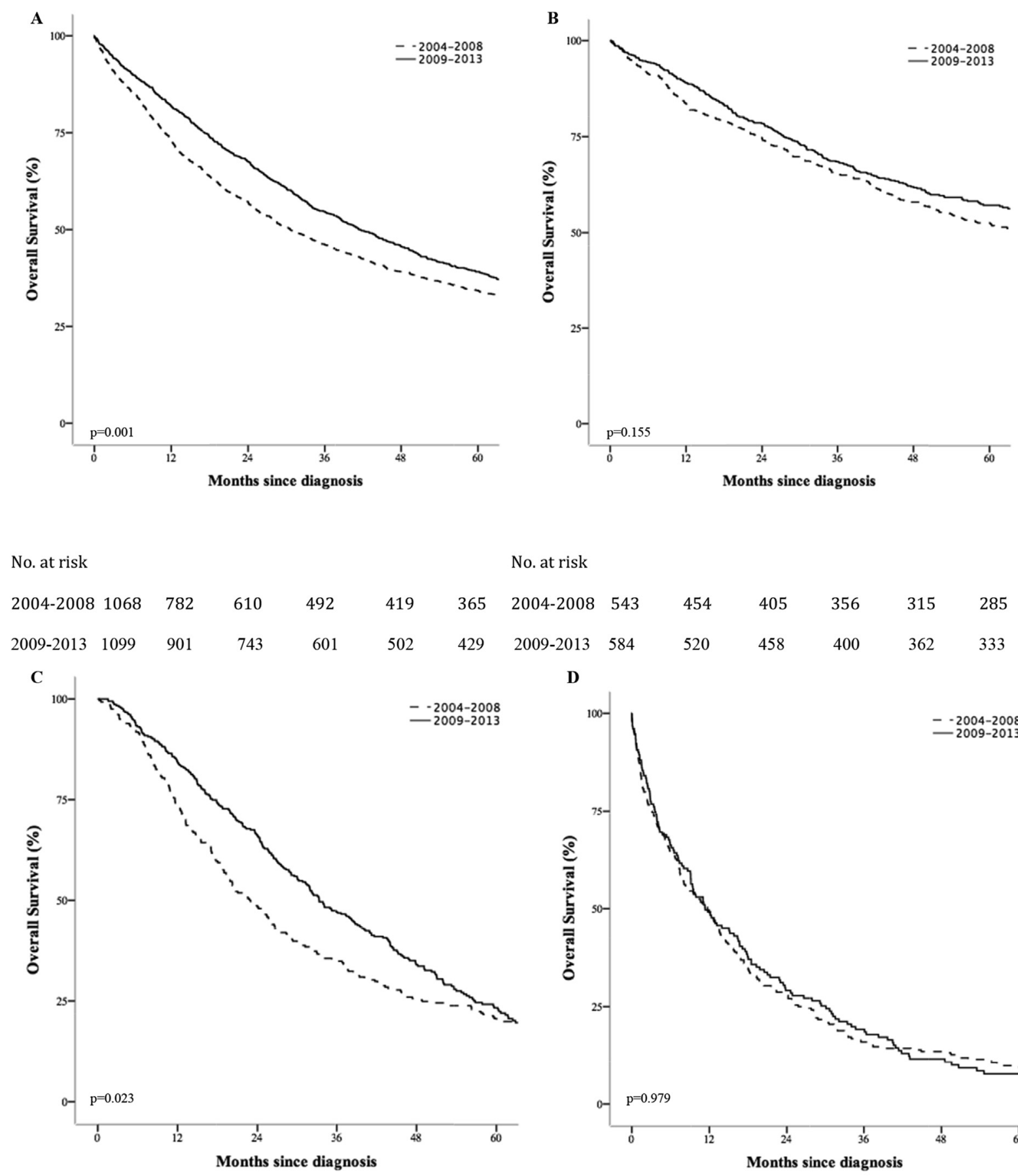

$\begin{array}{lrrrrrr}\text { No. at risk } & & & & & & \\ 2004-2008 & 543 & 454 & 405 & 356 & 315 & 285 \\ 2009-2013 & 584 & 520 & 458 & 400 & 362 & 333\end{array}$

D

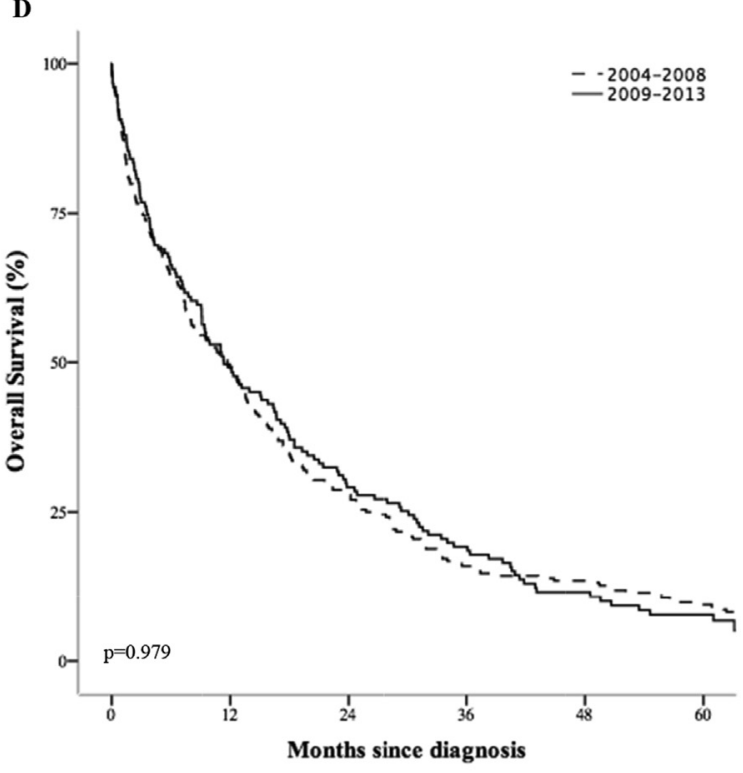

No. at risk

No. at risk

$\begin{array}{rrrrrrrrrrrrrr}2004-2008 & 281 & 208 & 136 & 98 & 71 & 58 & 2004-2008 & 244 & 120 & 69 & 39 & 33 & 23 \\ 2009-2013 & 364 & 307 & 241 & 172 & 124 & 85 & 2009-2013 & 151 & 74 & 44 & 29 & 18 & 12\end{array}$

Fig. 4. Overall survival for patients $\geq 65$ years with clinical stage I NSCLC by time period. (A) All patients; (B) surgical patients; (C) patients treated with radiotherapy; (D) neither therapy. NSCLC, non-small-cell lung cancer.

not consist of selected, relatively fit patients, which is often the case in clinical trials. Better patient selection could have influenced the OS outcome as surgical patients became older over time and had an increased comorbidity burden, while outcomes improved.
Therefore, unidentified or unrecorded factors, such as pulmonary function and performance status, probably have played a role in selecting patients for surgery. Poorer pulmonary function and performance status have been found associated with worse OS $[9,18]$, and 
Table 2

Multivariable analysis of factors associated with an increased hazard of death for elderly patients with clinical stage I NSCLC by primary treatment.

\begin{tabular}{|c|c|c|c|c|c|c|c|c|}
\hline \multirow[t]{2}{*}{ Characteristics } & \multicolumn{2}{|c|}{ All patients } & \multicolumn{2}{|c|}{ Surgery } & \multicolumn{2}{|c|}{ Radiotherapy } & \multicolumn{2}{|c|}{ Neither } \\
\hline & HR & $95 \% \mathrm{CI}$ & HR & $95 \% \mathrm{CI}$ & HR & $95 \% \mathrm{CI}$ & HR & $95 \% \mathrm{CI}$ \\
\hline \multicolumn{9}{|l|}{ Age } \\
\hline $65-74$ years & 1 (ref) & & 1 (ref) & & 1 (ref) & & 1 (ref) & \\
\hline$\geq 75$ years & 1.49 & $1.34-1.66$ & 1.33 & $1.12-1.58$ & 1.25 & $1.04-1.49$ & 1.35 & $1.07-1.69$ \\
\hline \multicolumn{9}{|l|}{ Gender } \\
\hline Female & 1 (ref) & & 1 (ref) & & 1 (ref) & & 1 (ref) & \\
\hline Male & 1.15 & $1.03-1.29$ & 1.27 & $1.06-1.53$ & 1.00 & $0.82-1.21$ & 1.11 & $0.87-1.40$ \\
\hline \multicolumn{9}{|l|}{ Comorbidities } \\
\hline Cardiac & 1.22 & $1.10-1.35$ & 1.21 & $1.03-1.42$ & 1.25 & $1.04-1.49$ & 1.03 & $0.83-1.27$ \\
\hline Vascular & 1.09 & $0.98-1.22$ & 1.06 & $0.89-1.26$ & 1.06 & $0.89-1.28$ & 1.25 & $0.99-1.57$ \\
\hline Pulmonary & 1.19 & $1.07-1.32$ & 1.20 & $1.02-1.41$ & 1.20 & $1.01-1.44$ & 1.10 & $0.89-1.36$ \\
\hline Diabetes & 1.14 & $1.00-1.30$ & 1.29 & $1.05-1.59$ & 1.27 & $1.02-1.58$ & 0.96 & $0.72-1.26$ \\
\hline Previous malignancy & 1.16 & $1.03-1.30$ & 1.42 & $1.19-1.71$ & 0.93 & $0.76-1.14$ & 1.00 & $0.78-1.28$ \\
\hline \multicolumn{9}{|l|}{ Histology pretreatment } \\
\hline Adenocarcinoma & 0.91 & $0.79-1.05$ & 0.90 & $0.72-1.12$ & 1.11 & $0.87-1.42$ & 0.95 & $0.70-1.28$ \\
\hline Squamous cell carcinoma & 0.85 & $0.74-0.99$ & 1.02 & $0.81-1.27$ & 0.96 & $0.74-1.24$ & 0.90 & $0.59-1.38$ \\
\hline Other & 1 (ref) & & 1 (ref) & & 1 (ref) & & 1 (ref) & \\
\hline \multicolumn{9}{|l|}{ Histopathologic confirmation } \\
\hline Yes & 1 (ref) & & & & 1 (ref) & & 1 (ref) & \\
\hline No & 1.64 & $1.43-1.87$ & & & 0.76 & $0.61-0.94$ & 0.98 & $0.74-1.31$ \\
\hline \multicolumn{9}{|l|}{ Period } \\
\hline 2004-2008 & 1.23 & $1.10-1.37$ & 1.20 & $1.01-1.43$ & 1.19 & $0.99-1.43$ & 1.03 & $0.82-1.29$ \\
\hline 2009-2013 & 1 (ref) & & 1 (ref) & & 1 (ref) & & 1 (ref) & \\
\hline \multicolumn{9}{|l|}{ cT stage ${ }^{\mathrm{a}}$} \\
\hline 1 & 1 (ref) & & 1 (ref) & & 1 (ref) & & 1 (ref) & \\
\hline 2 & 1.53 & $1.36-1.72$ & 1.39 & $1.18-1.63$ & 1.50 & $1.22-1.85$ & 1.14 & $0.83-1.58$ \\
\hline
\end{tabular}

NSCLC, non-small-cell lung cancer; HR, hazard ratio; CI, confidence interval.

Statistics in bold indicate a statistical significant difference.

${ }^{a}$ Owing to too many unknown cases (514), cT stage is not included in the multivariable analysis. The results shown for cT stage are from a univariable analysis.

treatment choice will partially depend on these and other patient characteristics ("confounding by indication'). Patients receiving radiotherapy became younger, which probably also contributed to better outcomes. Stage migration has probably occurred because of the introduction of TNM edition 7 in 2010. This may have beneficially affected the OS rate of patients in period $\mathrm{B}$ as from then on, stage I did no longer include tumours larger than $5 \mathrm{~cm}$. No histopathologic proof of malignancy was obtained in $72 \%$ and $68 \%$ of patients receiving radiotherapy and neither treatment, respectively. Although these percentages are high, it reflects Dutch clinical practice. A high comorbidity burden or poor performance status may be reasons for deciding not to obtain histopathologic proof of malignancy, as well as the probability of benign disease of only $4.3 \%$ if patients met multiple criteria as described previously [16]. The observational design is a limitation of this study, and causal relationships between treatment type and OS cannot be proven. Furthermore, follow-up was completed until February 2017, which implies that 5year follow-up was not complete for most of the patients diagnosed in 2012-2013. Another limitation is the fact that recurrence rates and causes of death are unknown.

In conclusion, this study provides a realistic overview of the current treatment patterns and OS among patients with stage I NSCLC in daily clinical practice in the Netherlands. The median OS improved over time for patients $\geq 65$ years. The increased application of SBRT is promising and could be associated with improved OS and a lower proportion of patients receiving neither treatment. Surgery was still associated with the highest long-term OS and should, therefore, be preferred for relatively fit elderly patients. SBRT seems an appropriate alternative for inoperable patients.

\section{Conflict of interest statement}

None declared.

\section{Funding}

This research did not receive any specific grant from funding agencies in the public, commercial or not-forprofit sectors.

\section{Acknowledgements}

The authors thank all registrars that registered the patients in the database, as well as the Netherlands Cancer Registry. They thank Winfried W.C. Gieskes 


\section{(University of Groningen, the Netherlands) for revising earlier versions of the manuscript.}

\section{References}

[1] Fitzmaurice C, Dicker D, Pain A, Hamavid H, Moradi-Lakeh M, MacIntyre MF, et al. The global burden of cancer 2013. JAMA Oncol 2015;1:505-27.

[2] Netherlands Cancer Registry. Nation wide mortality figures for lung cancer. Utrecht: Dutch Cancer Registration (IKNL); 2013. http://www.cijfersoverkanker.nl/. [Accessed 12 January 2016].

[3] Netherlands Cancer Registry. Nation wide incidence figures for lung cancer. Utrecht: Dutch Cancer Registration (IKNL); 2013. http://www.cijfersoverkanker.nl/. [Accessed 12 January 2016].

[4] Rijksinstituut voor volksgezondheid en milieu (RIVM). Future trend of new cases of lung cancer in The Netherlands [accessed 08.02.2018] http://www.volksgezondheidenzorg.info/onderwerp/ longkanker/cijfers-context/trends\#node-toekomstige-trendnieuwe-gevallen-longkanker.

[5] Driessen EJ, Aarts MJ, Bootsma GP, van Loon JG, JanssenHeijnen ML. Trends in treatment and relative survival among non-small cell lung cancer patients in The Netherlands (1990-2014): disparities between younger and older patients. Lung Canc 2017;108:198-204.

[6] Jaklitsch MT, Mery CM, Audisio RA. The use of surgery to treat lung cancer in elderly patients. Lancet Oncol 2003;4:463-71.

[7] Palma D, Visser O, Lagerwaard FJ, Belderbos J, Slotman BJ, Senan S. Impact of introducing stereotactic lung radiotherapy for elderly patients with stage I non-small-cell lung cancer: a population-based time-trend analysis. J Clin Oncol 2010;28: 5153-9.

[8] Haasbeek CJ, Palma D, Visser O, Lagerwaard FJ, Slotman B, Senan S. Early-stage lung cancer in elderly patients: a populationbased study of changes in treatment patterns and survival in The Netherlands. Ann Oncol 2012;23:2743-7.

[9] Detillon DDEMA, Veen EJ. Postoperative outcome after pulmonary surgery for non-small cell lung cancer in elderly patients. Ann Thorac Surg 2018;105:287-93.

[10] Berry MF, Onaitis MW, Tong BC, Harpole DH, D'Amico TA. A model for morbidity after lung resection in octogenarians. Eur J Cardio Thorac Surg 2011;39:989-94.

[11] Port JL, Mirza FM, Lee PC, Paul S, Stiles BM, Altorki NK. Lobectomy in octogenarians with non-small cell lung cancer: ramifications of increasing life expectancy and the benefits of minimally invasive surgery. Ann Thorac Surg 2011;92:1951-7.

[12] Shirvani SM, Jiang J, Chang JY, Welsh JW, Gomez DR, Swisher S, et al. Comparative effectiveness of 5 treatment strategies for early-stage non-small cell lung cancer in the elderly. Int $\mathrm{J}$ Radiat Oncol Biol Phys 2012;84:1060-70.

[13] Senthi S, Lagerwaard FJ, Haasbeek CJ, Slotman BJ, Senan S. Patterns of disease recurrence after stereotactic ablative radiotherapy for early stage non-small-cell lung cancer: a retrospective analysis. Lancet Oncol 2012;13:802-9.

[14] Bollen EC, Belgers E, van Haren EH, Siebenga J. Surgical treatment of lung cancer with complete VATS lobectomy, new in The Netherlands. Ned Tijdschr Geneeskd 2008;152:1204-9.

[15] Lagerwaard FJ, Verstegen NE, Haasbeek CJ, Slotman BJ, Paul MA, Smit EF, et al. Outcomes of stereotactic ablative radiotherapy in patients with potentially operable stage I nonsmall cell lung cancer. Int J Radiat Oncol Biol Phys 2012;83: $348-53$.

[16] Belgers EH, Siebenga J, Bosch AM, van Haren EH, Bollen EC. Complete video-assisted thoracoscopic surgery lobectomy and its learning curve. A single center study introducing the technique in The Netherlands. Interact Cardiovasc Thorac Surg 2010;10: 176-80.

[17] National Comprehensive Cancer Network Clinical Practice Guidelines. Non-small cell lung cancer. Comprehensive Cancer Centre the Netherlands; 2015. http://www.oncoline.nl/nietkleincellig-longcarcinoom. [Accessed 12 January 2018].

[18] Alexander M, Wolfe R, Ball D, Conron M, Stirling RG, Solomon B, et al. Lung cancer prognostic index: a risk score to predict overall survival after the diagnosis of non-small-cell lung cancer. Br J Cancer 2017;117:744-51.

[19] Zhang Z, Zhang Y, Feng H, Yao Z, Teng J, Wei D, et al. Is video-assisted thoracic surgery lobectomy better than thoracotomy for early-stage non-small-cell lung cancer? A systematic review and meta-analysis. Eur J Cardio Thorac Surg 2013;44 407-14.

[20] Puri V, Crabtree TD, Bell JM, Broderick SR, Morgensztern D, Colditz GA, et al. Treatment outcomes in stage I lung cancer: a comparison of surgery and stereotactic body radiation therapy. J Thorac Oncol 2015;10:1776-84.

[21] Chang JY, Senan S, Paul MA, Mehran RJ, Louie AV, Balter P, et al. Stereotactic ablative radiotherapy versus lobectomy for operable stage I non-small-cell lung cancer: a pooled analysis of two randomised trials. Lancet Oncol 2015;16:630-7. 